https://doi.org/10.15407/ujpe64.6.522

V.B. NEIMASH, ${ }^{1}$ A.S. NIKOLENKO ${ }^{2}$ V.V. STRELCHUK, ${ }^{2}$ P.YE. SHEPELYAVYI, ${ }^{2}$ P.M. LITVINCHUK,${ }^{1}$ V.V. MELNYK,${ }^{1}$ I.V. OLKHOVYK ${ }^{1}$

${ }^{1}$ Institute of Physics, Nat. Acad. of Sci. of Ukraine

(46, Nauky Ave., Kyiv 03028, Ukraine; e-mail: neimash@gmail.com)

${ }^{2}$ V.E. Lashkaryov Institute of Semiconductor Physics, Nat. Acad. of Sci. of Ukraine

(41, Nauky Ave., Kyiv 03028, Ukraine)

\title{
INFLUENCE OF LASER LIGHT ON THE FORMATION AND PROPERTIES OF SILICON NANOCRYSTALS IN a-Si/Sn LAYERED STRUCTURES
}

\begin{abstract}
The influence of the laser light intensity and the temperature on the tin-induced crystallization of amorphous silicon has been studied using the Raman screening and optical microscopy methods. The existence of non-thermal mechanisms giving rise to the influence of laser light on the formation of silicon nanocrystals and their Raman spectra is demonstrated experimentally. The photoionization of silicon and the electron-phonon interaction are considered as possible origins of the detected effects. The prospects of their application in new technologies for producing nano-silicon films used in solar cells are discussed.

Ke ywords: amorphous silicon, nanocrystals, crystallization, tin, laser.
\end{abstract}

\section{Introduction}

The film composite "Si nanocrystals in the amorphous Si matrix" (nc-Si) is a promising material for the next generation of solar cells (SCs) based on quantum dots [1]. It has a unique set of physical properties: the direct-band mechanism of light absorption, the dependence of the band gap width on the size of nanocrystals, the resistance to the Staebler-Wronski effect, and the ability to the formation on flexible substrates.

The application of nano-silicon for creating the isomorphic heterostructures of the cascade type $[2,3]$ can substantially enhance the efficiency and reduce the cost of SCs owing to the advantages of the thinfilm and rolling technologies [4,5]. Among the main problems that hamper the practical implementation of nc-Si advantages is an insufficient development of technologies aimed at controlling the size and concentration of $\mathrm{Si}$ nanocrystals at economically reasonable rates of film formation. Therefore, in spite of a large number of existing technologies for fab-

(C) V.B. NEIMASH, A.S. NIKOLENKO, V.V. STRELCHUK, P.YE. SHEPELYAVYI,

P.M. LITVINCHUK, V.V. MELNYK,

I.V. OLKHOVYK, 2019 ricating $\mathrm{nc}-\mathrm{Si}$, large attention is paid to improving them and searching for new ones (see. e.g., works [6-12]).

One of the promising ways in this direction is the application of the phenomenon of metal-induced crystallization (MIC) of amorphous silicon [13-17]. In particular, at the beginning of the 2010s, a possibility to form Si nanocrystals $2-5 \mathrm{~nm}$ in dimension with a phase-volume fraction of up to $80 \%$ in the matrix of amorphous Si was demonstrated with the help of the low-temperature tin-induced crystallization of amorphous Si [18-20]. The obtained experimental results were interpreted using a new mechanism of MIC proposed in works [20, 21] and theoretically substantiated in work [22]. This mechanism differs substantially from its counterparts known for other metals [13, 15-17]. According to this mechanism, silicon nanocrystals are formed as a result of the cyclic repetition of the formation and decay processes running in a supersaturated solution of silicon in tin in a narrow eutectic layer located at the interface between amorphous silicon and metal tin. It turned out that this mechanism can be initiated with the help of laser light with a relatively low intensity $\left(I \sim 10^{5} \mathrm{~W} / \mathrm{cm}^{2}\right)$, which is used to excite the Raman light scattering.

ISSN 2071-0194. Ukr. J. Phys. 2019. Vol. 64, No. 6 
In our work [23], when measuring the Raman spectra, we observed the formation of silicon nanocrystals a few nanometers in dimension in the layer of amorphous silicon belonging to a two-layer silicon-tin film. According to our measurements and estimates, owing to the absorption of the laser excitation energy, the film temperature at the site of the beam action could reach a value of $700{ }^{\circ} \mathrm{C}$. This temperature can initiate MIC processes that transform Si from the amorphous into the nanocrystalline state. The analysis of the Raman spectra registered at this moment makes it possible to measure not only the temperature, but also the size and concentration of nanocrystals. As a result, we can control the formation of nanocrystals by changing the intensity of laser light and the time of its action.

We also noticed [23] that the processes of silicon nanocrystal growth and accumulation run faster under laser irradiation than when the specimens were heated to the same temperature in dark. On this basis, we assumed that the photoionization of silicon somehow promotes the MIC processes. The results of our recent work [24] testify in favor of this assumption: we also observed the stimulating effect of short (10 ns), but powerful (up to $I \sim 10^{8} \mathrm{~W} / \mathrm{cm}^{2}$ ) single laser pulses on the MIC in the a-Si/Sn system.

In this work, we show that the processes of tininduced crystallization (TIC) of amorphous silicon can be accelerated by laser light, but without affecting the temperature. In addition, we demonstrate that the Raman spectrum of as-grown silicon nanocrystals, unlike the spectrum of monocrystalline silicon, is sensitive to the intensity of the exciting laser light even at a stable temperature.

\section{Experimental Part}

As experimental objects, we selected planar two-layer structures "amorphous silicon on metal tin" deposited onto the substrates fabricated from borosilicate glass (BSG) or monocrystalline silicon KEF-4.5. The structures were produced by successively depositing tin (a purity grade of $99.92 \%$ ) and silicon (a purity grade of $99.999 \%$ ), which were thermally evaporated in vacuum from tantalum evaporators heated by the electric current. The deposition was performed onto 1$\mathrm{mm}$ glass or $0.3-\mathrm{mm}$ silicon substrates at a temperature of about $150{ }^{\circ} \mathrm{C}$ in the following sequence: first, the tin layer was deposited onto the substrate; then the silicon layer was deposited onto the tin one. The thicknesses of the layers varied discretely within an interval of 50-200 nm with an increment of $50 \mathrm{~nm}$. The both deposition procedures were carried out in the same vacuum chamber without depressurization and under a residual pressure of $10^{-3} \mathrm{~Pa}$ by successively applying two different evaporators.

We have studied the behavior of the Raman spectra registered from the surface layer of the described structures at various substrate temperatures and at various intensities of exciting light.

The Raman spectra were measured in the geometry of backward scattering on a Horiba Jobin Yvon T64000 spectrometer equipped with an Olympus BX41 confocal microscope and a thermoelectrically cooled CCD detector. The corresponding spectral resolution was about $0.15 \mathrm{~cm}^{-1}$. The Raman spectra were excited using the line of an Ar-Kr laser with the wavelength $\lambda=488.0 \mathrm{~nm}$. The excitation radiation was focused with the help of an Olympus 50x lens $(\mathrm{NA}=0.5)$ on the surface of the test specimen into an area of about $1 \mu \mathrm{m}^{2}$. The maximum radiation power at the specimen was $10 \mathrm{~mW}(100 \%)$, or it was lowered by means of a neutral filter down to $50 \%$, $25 \%, 10 \%$, and $1 \%$. The corresponding power density of excitation radiation at the specimen varied from $10^{4}$ to $10^{6} \mathrm{~W} / \mathrm{cm}^{2}$.

When performing the temperature-dependent Raman measurements with a controlled thermal heating, the specimens were arranged in a Linkam THMS600 thermoelectric stage. The temperature in the stage was varied discretely in an interval of $20-550{ }^{\circ} \mathrm{C}$ with an accuracy of $\pm 0.1^{\circ} \mathrm{C}$. The Raman spectra were registered in a spectral interval of $100-850 \mathrm{~cm}^{-1}$. The time needed to scan this interval, i.e. the time of the laser-beam excitation of Raman spectra was 50 or $100 \mathrm{~s}$.

The surface of the specimens at the site of the exciting laser beam action and around it was monitored visually with the help an optical microscope equipped with a 50x lens and using a digital photocamera.

\section{Results and Their Discussion}

Figure 1 demonstrates the Raman spectra obtained for the BSG/Sn(100 nm)/a-Si(100 nm) structure on a glass substrate. The spectra were registered at the successively increased power of laser excitation. The spectrum scan time was $50 \mathrm{~s}$.

At low excitation powers, the form of Raman spectra (curves 1-3) is typical of amorphous sil- 


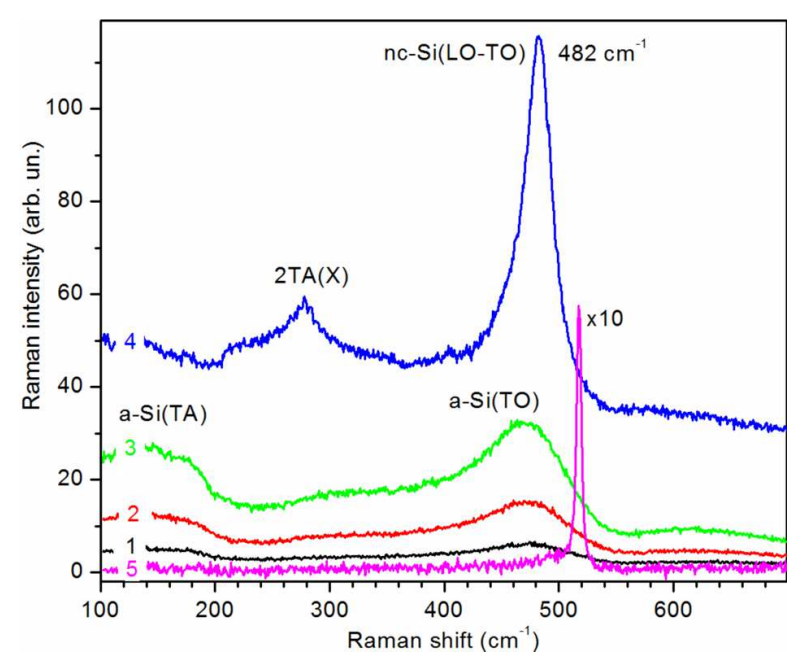

Fig. 1. Raman spectra of the $B S G / \operatorname{Sn}(100 \mathrm{~nm}) / \mathrm{a}-\mathrm{Si}(100 \mathrm{~nm})$ structure at various laser excitation powers $P=1$ (1), 2.5 (2), 5.0 (3), 10.0 (4), and $0.1 \mathrm{~mW}(5)$

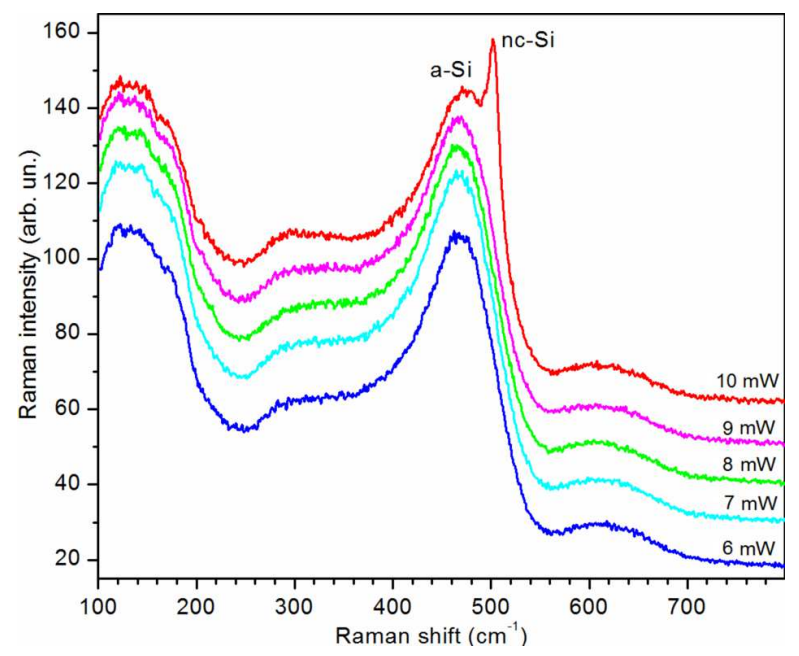

Fig. 2. Raman spectra of the BSG/Sn(150 nm)/a-Si(50 nm) structure at various laser excitation powers

icon: two broad bands with comparable intensities, half-widths of about $85 \mathrm{~cm}^{-1}$, and with the maxima located at about 150 and $470 \mathrm{~cm}^{-1}$. They correspond to the light scattering by acoustic TA and optical TO phonons, respectively, in the amorphous silicon phase. At the maximum exciting power $(10 \mathrm{~mW})$, there appears a narrow (a half-width of about $30 \mathrm{~cm}^{-1}$ ) and intense band of the crystalline silicon phase with a maximum at $482 \mathrm{~cm}^{-1}$ (Fig. 1). This peak survives, as the light power is reduced to the minimum $(0.1 \mathrm{~mW})$, but its maxi- mum shifts to $517 \mathrm{~cm}^{-1}$. It should be noted that the appearance of the characteristic two-phonon acoustic peak $2 \mathrm{TA}(\mathrm{X})$ belonging to the crystalline silicon phase in the spectrum testifies in favor of the proposed classification for the $482-\mathrm{cm}^{-1}$ band. A similar behavior of the nanocrystalline silicon band, as the laser excitation power changes, was analyzed in work [29] in detail. The analysis of the spectrum obtained at an excitation power of $0.1 \mathrm{~mW}$, which was carried out following the method described in works [25,26], testifies to the formation of silicon nanocrystals with the dominant size $R=5 \mathrm{~nm}$ and a volume concentration exceeding $X_{\mathrm{C}}=58$ vol.\% at the site, where the Raman spectrum was measured.

In the $\mathrm{BSG} / \mathrm{Sn}(150 \mathrm{~nm}) / \mathrm{a}-\mathrm{Si}(50 \mathrm{~nm})$ specimens on the glass substrate, the conditions of heat removal in the silicon layer from the site of laser action were somewhat better due to a larger thickness of the metal layer and a narrower silicon layer. Because of those circumstances, the crystallization in this case was obviously slower, although, again, it occurred, only if the laser power equaled $10 \mathrm{~mW}$. The Raman spectra registered for a specimen with this structure are shown in Fig. 2. One can see that a gradual increase in the power to $9 \mathrm{~mW}$ inclusively did not provoke any manifestations of the crystalline component in the Raman spectrum.

However, a further power growth to $10 \mathrm{~mW}$ resulted in a jump-like appearance of a band with a maximum at $501 \mathrm{~cm}^{-1}$ belonging to the crystalline component. Six additional 50-s scans of the spectrum at the same site of the specimen surface (i.e. the accumulation of the laser action time) at the power $P=10 \mathrm{~mW}$ resulted in a shift of the maximum position of this band to $494 \mathrm{~cm}^{-1}$ and a weak growth of its amplitude. This process is illustrated in Fig. 3, which demonstrates the evolution of the main Raman band, as the laser operating time grows from 50 to $350 \mathrm{~s}$.

The threshold character of the TIC dependence on the laser light power was also observed in our work [24]. In the cited work, we assumed that the threshold is associated with the reaching of the tin melting temperature $\left(230{ }^{\circ} \mathrm{C}\right)$, which almost coincides with the eutectic point for the Si-Sn pair. Actually, according to the results of works [20-22], tin stimulates the crystallization of amorphous silicon by passing it through the state of liquid eutectic.

Really, the traces of the laser action remained on the specimen surface after the crystallization, and 
they were visible on an optical microscope, as is shown in Fig. 4. They had the form of concentric circles that were srtongly different in contrast. An assumption can be made that a black spot about $1 \mu \mathrm{m}$ in diameter located at the center is associated with the amorphous-crystalline Si composite, whose Raman spectrum we observed. A light ring around the central spot can be due to a rise of molten tin to the surface. A next wide dark circle of the quasidendrite form can be a zone of the lateral crystallization directed from the previous tin ring. Finally, the outer light circle is similar to a depression, a deformation region of the amorphous silicon film surface as a result of the reduction of its thickness owing to the transverse crystallization from the bottom induced by molten tin in the lower layer. The lateral crystallization induced by tin drops was demonstrated in work [20].

It should be noted that spots of different sizes and shapes, which can be characterized by at least three contrast levels, also appeared on the surface of similar specimens after their annealing in dark for $30 \mathrm{~min}$ at a temperature of $300{ }^{\circ} \mathrm{C}$. But the corresponding Raman spectra contained only the bands of amorphous silicon and tin oxide without any indications of crystalline silicon. In other words, the application of laser light $10 \mathrm{~mW} / \mu \mathrm{m}^{2}$ in power for $1-6 \mathrm{~min}$ can transform about one-half of silicon contained in the layered a-Si/Sn structure from the amorphous into the crystalline state. Under the dark conditions, the heat treatment with the same result requires a time interval that is at least an order of magnitude larger.

There are at least two reasons for that: (i) in the region of the laser beam action, the temperature is much higher than $300{ }^{\circ} \mathrm{C}$, and (ii) there exists a nonthermal mechanism of light-stimulated TIC in amorphous silicon. To test those assumptions, the following experiments were carried out.

In order to reduce the local heating of the specimen at the site of the laser beam incidence, we enhanced the heat removal by replacing the substrate material with a more heat conductive one. A layered structure of amorphous silicon and metal tin with the same thickness ratio was fabricated under identical conditions, but on a monocrystalline silicon substrate $300 \mu \mathrm{m}$ in thickness and with a specific resistance of $4.5 \Omega \mathrm{cm}$. The thermal conductivity of this substrate was much higher than that of borosilicate glass. The band of crystalline silicon at $520 \mathrm{~cm}^{-1}$ in the Raman

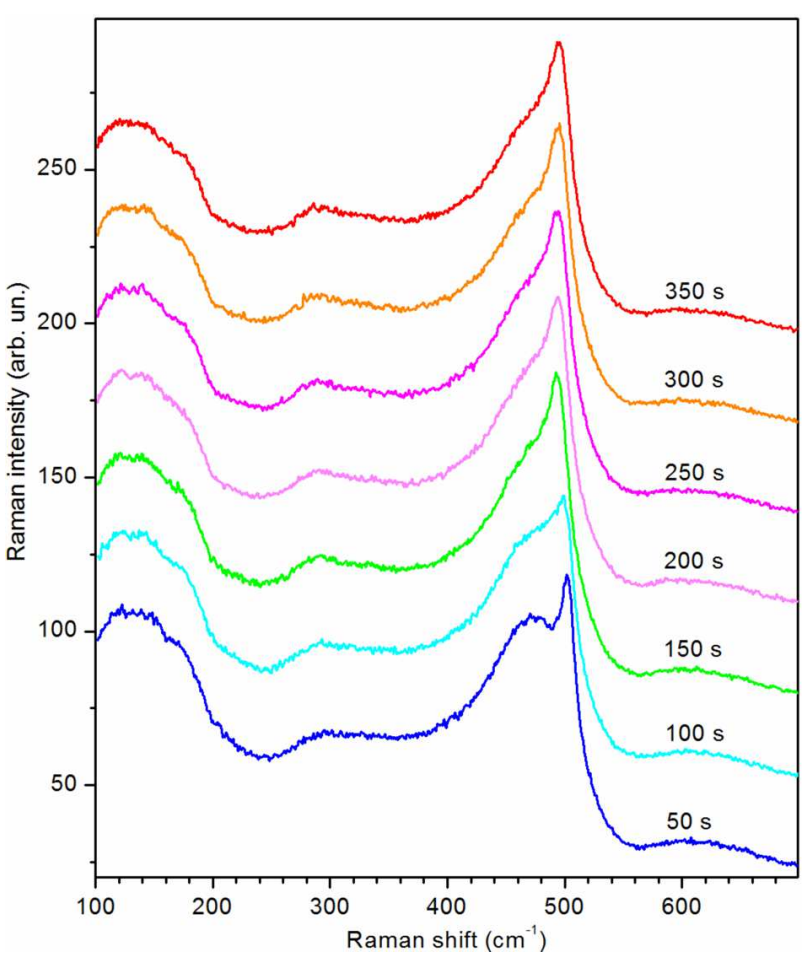

Fig. 3. Influence of the $10-\mathrm{mW}$ laser light action with various duration times on the Raman spectrum shape

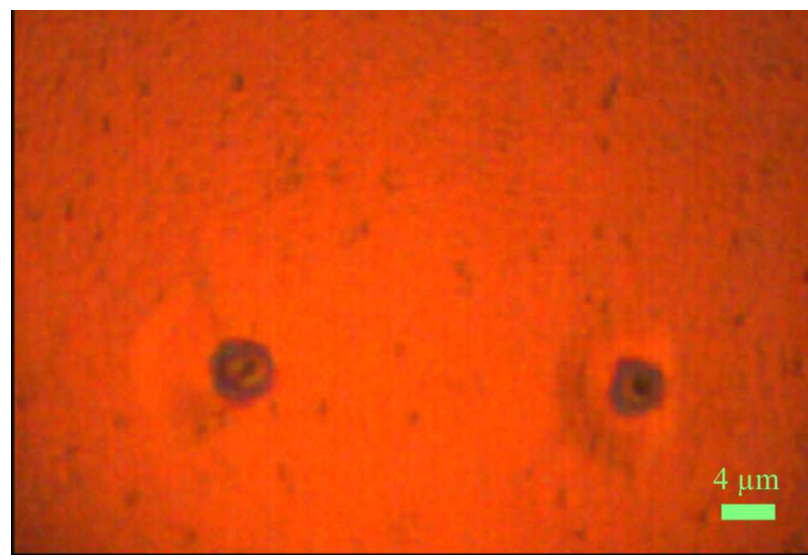

Fig. 4. Optical microphotos of the surface of a tested specimen. Two concentric spots are typical traces of the action of a 10-mW laser beam

spectrum of this substrate registered at room temperature changed its position by no more than $0.2 \mathrm{~cm}^{-1}$, when the Raman excitation power was changed from 0.1 to $10 \mathrm{~mW}$. In other words, at the site of laser excitation focusing, the substrate temperature increased by no more than $10{ }^{\circ} \mathrm{C}$ even at the maximum exci- 

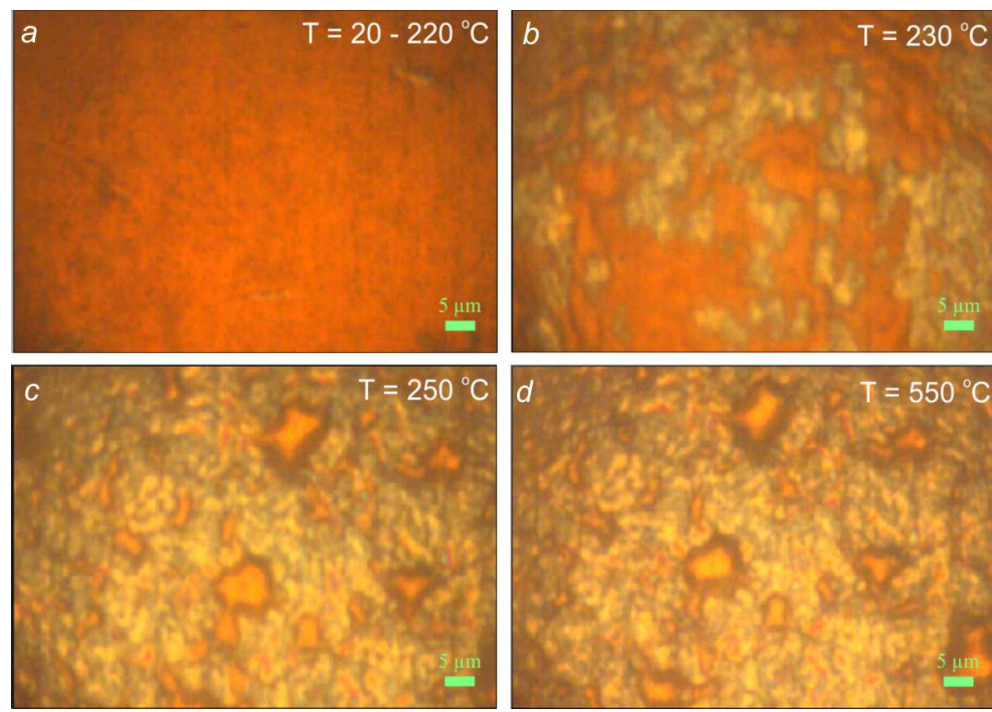

Fig. 5. Images the specimen surface at the temperatures $T=20 \div 220($ a), $230(b), 250(c)$, and $550{ }^{\circ} \mathrm{C}(d)$

tation power $[27,28]$. The influence of the substrate temperature and the laser radiation power on the Raman spectra of the c-Si/Sn(150 nm)/a-Si(50 nm) structure was studied in a temperature interval of 20 $550{ }^{\circ} \mathrm{C}$ with the help of a Linkam THMS600 thermoelectric stage, which automatically maintained a constant temperature with an accuracy of $\pm 0.1^{\circ} \mathrm{C}$.

No effect of laser light on the OIC of amorphous silicon in the examined structure located on the silicon substrate was registered in the whole laser power interval ranging from 0.1 to $10 \mathrm{~mW}$ both at room temperature of the specimen and even when the latter was heated in the furnace up to $T=220{ }^{\circ} \mathrm{C}$. Only at a temperature of $230{ }^{\circ} \mathrm{C}$ and above, when there appeared indications that the tin layer was melting, the laser radiation with maximum power induced the rapid crystallization of amorphous silicon, as occurred in the structures on the glass substrate.

Figure 5 demonstrates how the image of the test specimen surface observed with the optical microscope changes during the process of specimen heating in the thermoelectric stage. The initial homogeneous surface of the specimen before its heating was crimson-colored (Fig. 5, a). Within a temperature interval of $230-240{ }^{\circ} \mathrm{C}$, which was passed during 2-3 min, green-yellow spots appeared and grew rapidly (Fig. 5, b). This process was evidently associated with the transition of tin in the layer into the liquid state. The latter process, if occurring in thin layers, is accompanied by the formation of microscopic tin droplets $[20,23]$, which tear the outer, three times thinner, film of amorphous silicon. In a time interval of 7-8 min, when the temperature stabilized at $T=250{ }^{\circ} \mathrm{C}$, the areas of the crimson and yellow-green regions became approximately comparable, as is shown in Fig. 5, c. In 2-3 min more, the growth of yellow-green areas gradually terminated. A subsequent elevation of the temperature to $550{ }^{\circ} \mathrm{C}$ resulted only in a certain increase of dark halos around the yellow spots owing to the diminishing of the latter (Fig. 5, d).

The Raman spectrum registered in the crimsoncolored regions corresponded to the spectrum of amorphous silicon. The spectrum obtained in the yellow-green areas contained a crystalline component. At $T=230{ }^{\circ} \mathrm{C}$, its phonon band was located at a frequency of $515.3 \mathrm{~cm}^{-1}$ (Fig. 6), and its amplitude firstly increased almost twice during $10 \mathrm{~min}$ and did not change afterward. Simultaneously, the temperature growth brought about a shift of the peak toward lower frequencies at a rate of $2 \mathrm{~cm}^{-1}$ per $100{ }^{\circ} \mathrm{C}$, and the band itself, in both its position and shape, coincided with the spectrum of the monocrystalline silicon substrate (it had a symmetric contour with a halfwidth of $6.7 \mathrm{~cm}^{-1}$ at $230{ }^{\circ} \mathrm{C}$ ), which is shown in Fig. 6 in the normalized form for comparison. The facts described above unambiguously identify this band as the Raman scattering from the monocrystalline sub-

ISSN 2071-0194. Ukr. J. Phys. 2019. Vol. 64, No. 6 
strate. It is evident that its observation became possible owing to the spatial gaps between microscopic tin droplets, which were formed under the action of surface tension forces in the layer of molten tin, which has poor adhesion to the silicon substrate. The formation of microscopic tin droplets under similar conditions was observed in works [20,23]. In our case, the gradual saturation of the $515.3-\mathrm{cm}^{-1}$-band intensity in time can be explained by the termination of the process of tin droplet formation and the corresponding increase of the intervals between the droplets, through which the light can reach the silicon substrate heated to $250{ }^{\circ} \mathrm{C}$.

A further increase of the temperature from 250 to $550{ }^{\circ} \mathrm{C}$ did not affect the amplitude of this band, but shifted its maximum toward lower frequencies. After the specimen had been cooled down to room temperature, the peak maximum was located at about $520 \mathrm{~cm}^{-1}$. Figure 7 shows the dependence of the frequency corresponding to the maximum of this band on the specimen temperature. One can see that it has a linear character and completely corresponds to the temperature dependence of the phonon band position for monocrystalline silicon $[27,28]$.

This band was used as a reference while studying the influence of laser excitation power on the Raman spectrum of this structure. Figure 8 shows the Raman spectra registered for a specimen heated to $250{ }^{\circ} \mathrm{C}$ at various excitation powers $P$ increasing from 1 to $10 \mathrm{~mW}$. One can see that, for the power values of $1,2.5$, and $5 \mathrm{~mW}$, there was only one band of the crystalline phase in the spectra; this was the band of the monocrystalline substrate, and it was located at $514.9 \mathrm{~cm}^{-1}$. At $P=10 \mathrm{~mW}$, there appeared a band of the nanocrystalline component at $496 \mathrm{~cm}^{-1}$ and with a half-width of $24 \mathrm{~cm}^{-1}$ (like a band at $492 \mathrm{~cm}^{-1}$ for the similar structure on the glass substrate). Its amplitude was at once almost thrice as large as the amplitude of the phonon band of the substrate, whose frequency position remained constant at $514.9 \mathrm{~cm}^{-1}$. The invariant position of the substrate band peak in the whole examined power interval testified to the absence of the laser radiation influence on the temperature of the examined site of the specimen. However, laser radiation did initiate the formation of Si nanocrystals. This means that a nonthermal mechanism of laser-assisted TIC took place.

Two additional scans of the spectrum (curves 5 and 6 in Fig. 8) at $P=10 \mathrm{~mW}$ (i.e. an additional

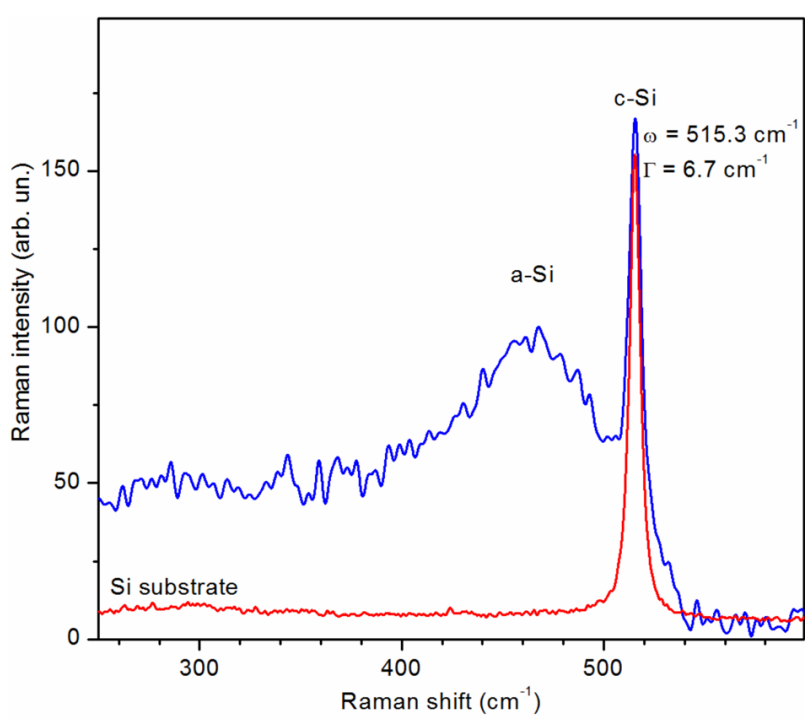

Fig. 6. Raman spectra of the c-Si $/ \mathrm{Sn}(150 \mathrm{~nm}) / \mathrm{a}-\mathrm{Si}(50 \mathrm{~nm})$ structure (upper curve) and the monocrystalline silicon substrate (lower curve). $T=230^{\circ} \mathrm{C}, P=2.5 \mathrm{~mW}$

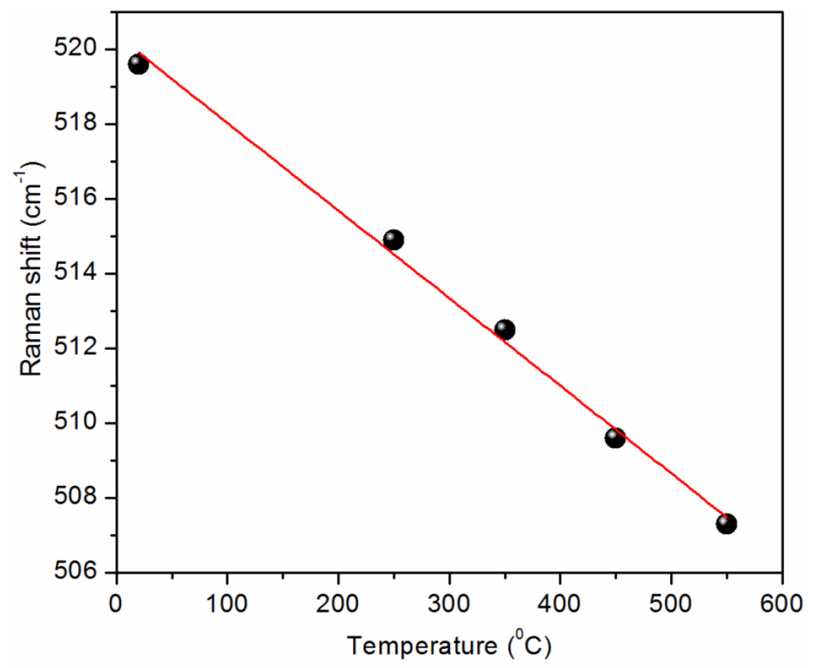

Fig. 7. Temperature dependence of the frequency position of a phonon band of the crystalline silicon phase that appeared in the $\mathrm{c}-\mathrm{Si} / \mathrm{Sn}(150 \mathrm{~nm}) / \mathrm{a}-\mathrm{Si}(50 \mathrm{~nm})$ structure at $T=230{ }^{\circ} \mathrm{C}$. $P=2.5 \mathrm{~mW}$. Points correspond to experimental data, the line is their linear approximation

holding of the specimen under laser light for $100 \mathrm{~s}$ at $250^{\circ} \mathrm{C}$ ) practically affected neither the amplitude nor the frequency position of the nanocrystalline phonon band. This means that the formation of nanocrystals under the indicated experimental conditions occurred very quickly and terminated within a time interval shorter than one-half of the spectrum scan time, $25 \mathrm{~s}$. 


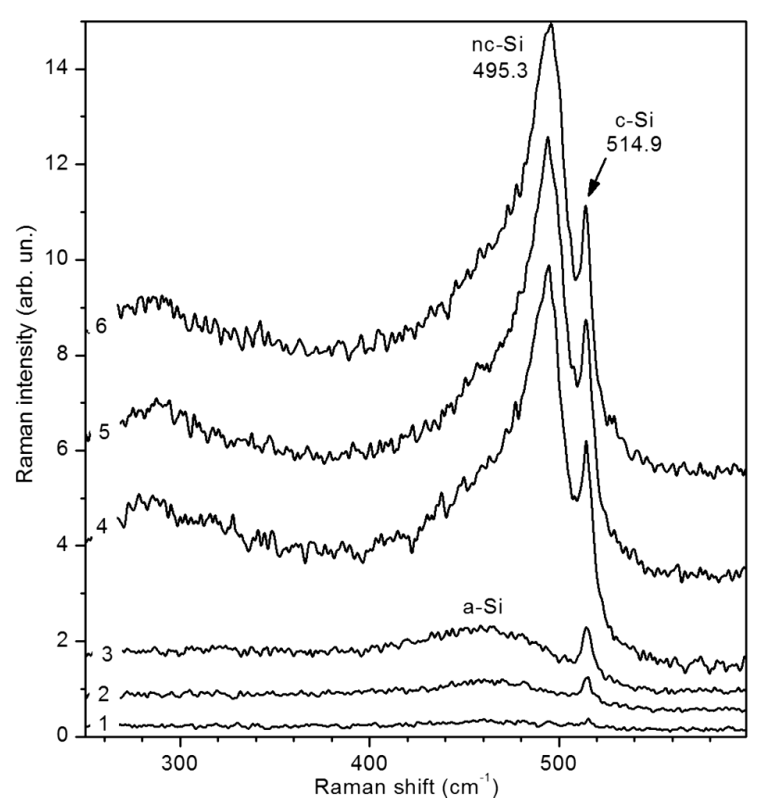

Fig. 8. Evolution of the Raman spectra of the c-Si/ $\mathrm{Sn}(150 \mathrm{~nm}) / \mathrm{a}-\mathrm{Si}(50 \mathrm{~nm})$ structure heated to $T=250{ }^{\circ} \mathrm{C}$ with the growth of the laser excitation power $P=1$ (1), 2.5 (2), 5 (3), and $10 \mathrm{~mW}(4,5,6)$

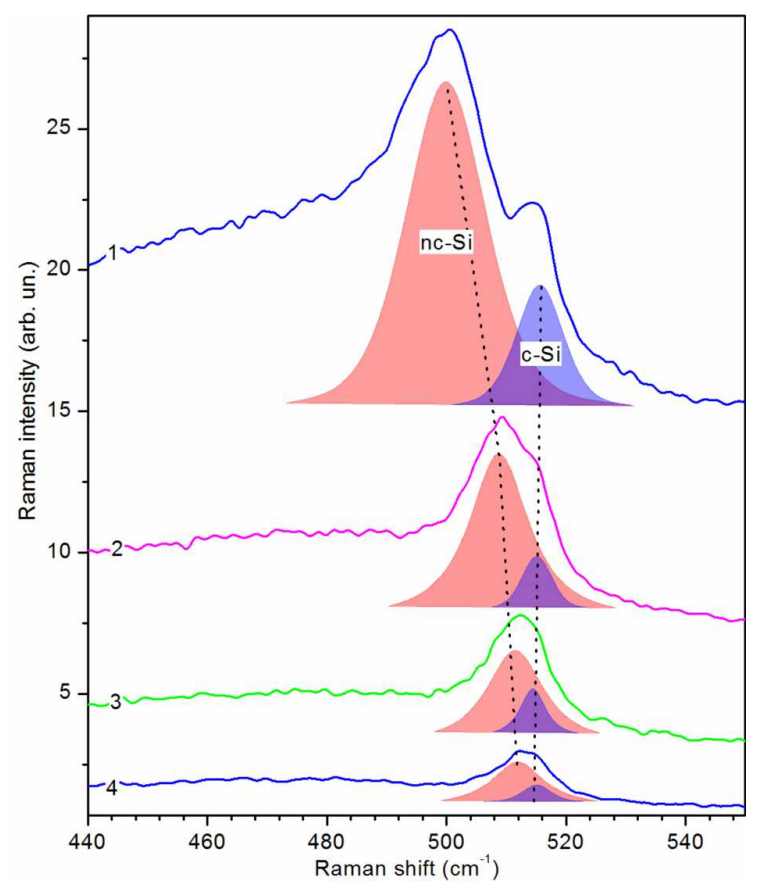

Fig. 9. Evolution of the Raman spectra of the c-Si/ $\mathrm{Sn}(150 \mathrm{~nm}) / \mathrm{a}-\mathrm{Si}(50 \mathrm{~nm})$ structure heated to $T=250{ }^{\circ} \mathrm{C}$ with the decrease of the laser excitation power $P=10$ (1), 5 (2), 2.5 (3), and $1 \mathrm{~mW}(4)$
A similar character of the influence of the laser radiation intensity on the TIC was observed at all temperatures higher than $230{ }^{\circ} \mathrm{C}$, i.e. above the tin melting point. Thus, the liquid state of tin and a light power density of $10 \mathrm{~mW} / \mu \mathrm{m}^{2}$ and higher are necessary but, if separately, not sufficient conditions for the laser-assisted acceleration of the TIC in the a-Si/Sn system. Only their simultaneous combination can accelerate the crystallization of amorphous silicon by at least an order of magnitude as compared with the heat treatment in dark. This result completely agrees with the data of our previous works [23,24], in which an issue was raised about the non-thermal origin of the stimulating light influence on the MIC of amorphous silicon.

The existence of the reference Raman band belonging to the monocrystalline substrate made it possible to explicitly demonstrate the dependence of the Raman scattering by silicon nanocrystals on the intensity of the laser light excitation at a stable specimen temperature. In Fig. 9, the evolution of the Raman spectra registered from the structure on the silicon substrate similar to the previous one, but after the crystallization, when the power of laser radiation was decreased from 10 to $1 \mathrm{~mW}$, is shown. One can see that the nanocrystalline peak shifts from $500.5 \mathrm{~cm}^{-1}$ at $P=10 \mathrm{~mW}$ to $509.5 \mathrm{~cm}^{-1}$ at $P=5 \mathrm{~mW}$, to $512 \mathrm{~cm}^{-1}$ at $P=2.5 \mathrm{~mW}$, and finally to $513 \mathrm{~cm}^{-1}$ at $P=1 \mathrm{~mW}$ to overlap the peak of the monocrystalline substrate located at $515 \mathrm{~cm}^{-1}$, the frequency position of which does not respond to the light power change in this interval (see Fig. 8).

A similar influence of the laser light power used for the Raman excitation on the frequency position of the nanocrystalline silicon band was observed at all temperatures in the examined interval. In particular, Fig. 10 shows that, already at room temperature, the band of the crystalline Si phase formed at $T=250{ }^{\circ} \mathrm{C}$ splits into two components, as the power in the laser beam causing the Raman excitation increases. One can see that a single, at $P=2.5 \mathrm{~mW}$, band of the $\mathrm{Si}$ crystalline phase located at about $518 \mathrm{~cm}^{-1}$ becomes split at $P=10 \mathrm{~mW}$ into the $520-\mathrm{cm}^{-1}$ band of the substrate and the $508-\mathrm{cm}^{-1}$ band of nanocrystals.

The results of studies of the Raman spectra measured at different sites of the $\mathrm{c}-\mathrm{Si} / \mathrm{Sn}(150 \mathrm{~nm}) / \mathrm{a}$ $\mathrm{Si}(50 \mathrm{~nm})$ structure, at various laser excitation intensities, and at temperatures of 230 and $250{ }^{\circ} \mathrm{C}$ are given in Fig. 11. In particular, the figure demon- 
strates the dependence of the frequency positions of the phonon peaks belonging to the nanocrystalline phase (curves 1-3) and the monocrystalline substrate (curves 4-6) on the laser excitation intensity. One can see that the position of the phonon peak belonging to the substrate does not depend on the laser excitation intensity. At the same time, the peak belonging to nanocrystalline silicon is substantially shifted toward lower frequencies, and this shift increases nonlinearly with the light intensity.

Thus, unlike the Raman spectrum of monocrystalline silicon, the Raman spectrum of nanocrystalline silicon is sensitive to the intensity of exciting radiation. This sensitivity is not a result of the laserinduced temperature change, but is associated with the optical factor of laser light. This result agrees with the data of works $[29,30]$, in which an abnormally strong "red shift" and the broadening of the phonon band of Si nanocrystals stimulated by a highintensity laser irradiation were observed. This effect was explained in work [30] as a combined influence of two effects: the laser heating of nanocrystallites and the nonequilibrium population of phonons. The latter arises as a result of the electron-phonon interaction between photoinduced charge carriers owing to a high rate of their generation at high excitation powers. A short diffusion length of photoexcited charge carriers - it equals only about $0.2 \AA$ in a system of silicon nanocrystals, which is considerably smaller than the diameter of the focused laser beam used for Raman excitation (about $1 \mu \mathrm{m}$ ) - leads to a high excitation rate of optical phonons, which cannot decay sufficiently quickly into acoustic phonons. Under those conditions, a non-thermal distribution of phonons is established in the measurement region. This distribution depends on the optical excitation level, which ultimately affects the Raman spectrum of nanocrystals and gives rise to both the low-frequency shift of the nanocrystalline phonon band and the distortion of the intensity ratio between the Stokes and anti-Stokes spectral components.

In work [30], poorly heat-conductive porous (a porosity of 30-40\%) films of silicon nanocrystals in a silicon oxide shell, which were deposited on also poorly heat-conductive glass substrates, were studied, and it was found that the effect of the laser heating of nanocrystallites could be substantial. But in our case, this heating is unlikely, because nanocrystals have a good thermal contact with metal tin, since

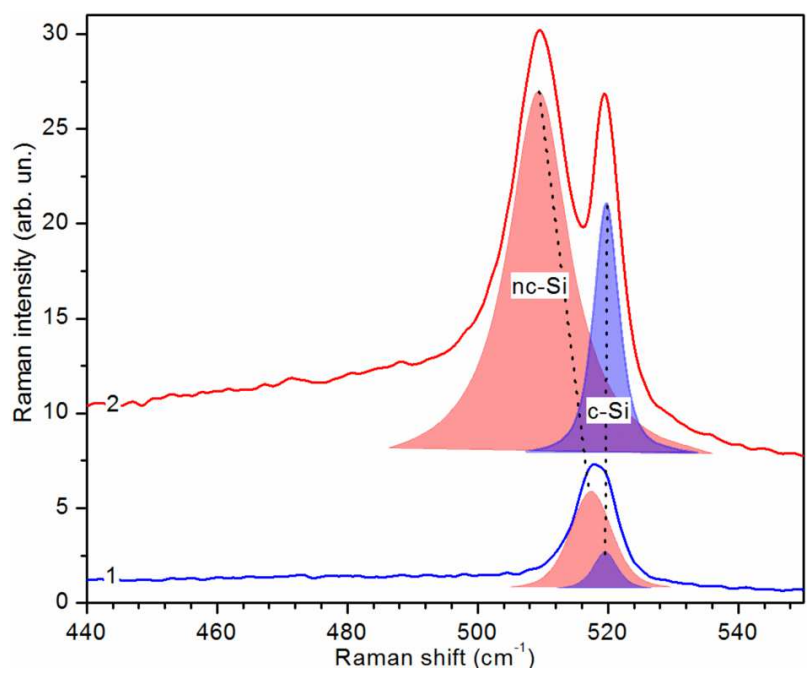

Fig. 10. Raman spectra of the c-Si $/ \mathrm{Sn}(150 \mathrm{~nm}) / \mathrm{a}-\mathrm{Si}(50 \mathrm{~nm})$ structure laser-modified at $T=250{ }^{\circ} \mathrm{C}$. The measurement temperature $T=23^{\circ} \mathrm{C}$, and the laser excitation power $P=2.5$ (1) and $10 \mathrm{~mW}(2)$

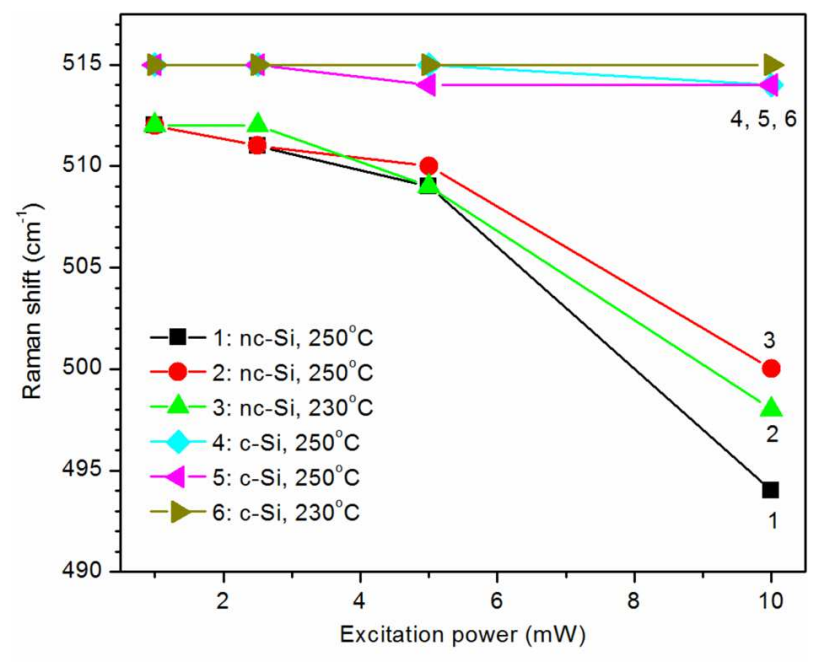

Fig. 11. Dependences of the frequency positions of the Raman bands of nanocrystallites (1,2,3) and monocrystalline substrate $(4,5,6)$ on the laser excitation power at the temperatures $T=250(1,2,4,5)$ and $230{ }^{\circ} \mathrm{C}(3,6)$

they are formed as a result of the decay of the silicon solution in tin, which is a good conductor of heat to the silicon substrate. Hence, the specific feature of our experiment consists in that its conditions allow the influence of the optical factor of the laser radiation action to be separated in a pure form from the thermal factor. 
It is not excluded that the revealed non-thermal factor of the laser light action on the tin-induced crystallization of amorphous silicon is also associated with the presence of non-equilibrium photo-induced charge carriers. For instance, it can be due to the facilitation of the amorphous silicon dissolution in tin as a result of the interatomic bond weakening, the formation of holes in those bonds, and screening by electrons created in the course of photoionization. This result can be an important step in the development of the manufacture technology and control over the quality of nanocrystalline silicon films for isomorphic solar cells of the cascade type. It is so because the existence of a non-thermal mechanism stimulating tininduced crystallization of amorphous silicon opens the prospect for a significant reduction of the temperature at the nanocrystal formation. Taking into account that the temperature confines the maximum size of nanocrystals, this circumstance makes it possible to smoothly control their size and, accordingly, the band gap width.

\section{Conclusions}

The existence of a non-thermal factor in the stimulating influence of laser light on the processes of tininduced silicon transformation from the amorphous into the nanocrystalline state has been proved experimentally for the first time. It is shown experimentally that there exists a non-thermal mechanism giving rise to the dependence of the Raman spectra of silicon nanocrystals on the excitation light intensity, which is absent for the monocrystalline Si state. This result testifies in favor of a hypothesis proposed in the recent paper [30] that the phonon spectrum in nc-Si can change as a result of the electron-phonon interaction with photoinduced charge carriers.

1. M.C. Beard, J.M. Luther, A.J. Nozik. The promise and challenge of nanostructured solar cells. Nat. Nano 9, 951 (2014).

2. Z.I. Alferov, V.M. Andreev, V.D. Rumyantsev. Solar photovoltaics: Trends and prospects. Semiconductors 38, 899 (2004).

3. B. Yan, G. Yue, X. Xu, J. Yang, S. Guha. High efficiency amorphous and nanocryistalline sillicon solar cells. Phys. Status Solidi A 207, 671 (2010).

4. N.S. Lewis. Toward cost-effective solar energy use. Science 315, 798 (2007).

5. R. Søndergaard, M. Hösel, D. Angmo, T.T. Larsen-Olsen, F.C. Krebs. Roll-to-roll fabrication of polymer solar cells. Mater. Today 15, 36 (2012).
6. M. Birkholz, B. Selle, E. Conrad, K. Lips, W. Fuhs. Evolution of structure in thin microcrystalline silicon films grown by electron-cyclotron resonance chemical vapor deposition. J. Appl. Phys 88, 4376 (2000).

7. B. Rech, T. Roschek, J. Müller, S. Wieder, H. Wagner. Amorphous and microcrystalline silicon solar cells prepared at high deposition rates using $\mathrm{RF}(13.56 \mathrm{MHz})$ plasma excitation frequencies. Sol. Energy Mater. Sol. Cells 66, 267 (2001).

8. M.K. van Veen, C.H.M. van der Werf, R.E.I. Schropp. Tandem solar cells deposited using hot-wire chemical vapor deposition, J. Non. Cryst. Solids 338-340, 655 (2004).

9. Y. Mai, S. Klein, R. Carius, H. Stiebig, L. Houben, X. Geng, F. Finger. Improvement of open circuit voltage in microcrystalline silicon solar cells using hot wire buffer layers. J. Non-Cryst. Solids 352, 1859 (2006).

10. H. Li, R.H. Franken, R.L. Stolk, C.H.M. van der Werf, J.K. Rath, R.E.I. Schropp. Controlling the quality of nanocrystalline silicon made by hot-wire chemical vapor deposition by using a reverse $\mathrm{H} 2$ profiling technique, J. Non-Cryst. Solids 354, 2087 (2008).

11. R. Amrani, F. Pichot, L. Chahed, Y. Cuminal. Amorphous-nanocrystalline transition in silicon thin films obtained by argon diluted silane PECVD, Cryst. Struct. Theor. Appl. 1, 57 (2012).

12. G. Fugallo, A. Mattoni. Thermally induced recrystallization of textured hydrogenated nanocrystalline silicon. Phys. Rev. B 89, 045301 (2014).

13. O. Nast, A.J. Hartmann. Influence of interface and $\mathrm{Al}$ structure on layer exchange during aluminum-induced crystallization of amorphous silicon. J. Appl. Phys. 88, 716 (2000).

14. M. Jeon, C. Jeong, K. Kamisako. Tin induced crystallisation of hydrogenated amorphous silicon thin films. Mater. Sci. Technol. 26, 875 (2010).

15. M.A. Mohiddon, M.G. Krishna. Growth and optical properties of Sn-Si nanocomposite thin films. J. Mater. Sci. 47, 6972 (2012).

16. D. Van Gestel, I. Gordon, J. Poortmans. Aluminuminduced crystallization for thin-film polycrystalline silicon solar cells: Achievements and perspective. Sol. Energy Mater. Sol. Cells 119, 261 (2013).

17. A. Mohiddon, G. Krishna. Metal induced crystallization. In Crystallization - Science and Technology. Edited by A. Marcello (InTech, 2012), p. 461.

18. V.V. Voitovych, V.B. Neimash, N.N. Krasko, A.G. Kolosiuk, V.Y. Povarchuk, R.M. Rudenko, V.A. Makara, R.V. Petrunya, V.O. Juhimchuk, V.V. Strelchuk. The effect of Sn impurity on the optical and structural properties of thin silicon films. Semiconductors 45, 1281 (2011).

19. V.B. Neimash, V.M. Poroshin, A.M. Kabaldin, V.O. Yukhymchuk, P.E. Shepelyavyi, V.A. Makara, S.Y. Larkin. Microstructure of thin Si-Sn composite films. Ukr. J. Phys. 58, 865 (2013).

20. V. Neimash, V. Poroshin, P. Shepeliavyi, V. Yukhymchuk, V. Melnyk, A. Kuzmich, V. Makara, A.O. Goushcha. Tin

ISSN 2071-0194. Ukr. J. Phys. 2019. Vol. 64, No. 6 
induced a-Si crystallization in thin films of Si-Sn alloys. J. Appl. Phys. 114, 213104 (2013).

21. V.B. Neimash, A.O. Goushcha, P.E. Shepeliavyi, V.O. Yukhymchuk, V.A. Dan'ko, V. Melnyk, A. Kuzmich. Mechanism of tin-induced crystallization in amorphous silicon. Ukr. J. Phys. 59, 1168 (2014).

22. V.B. Neimash, A.O. Goushcha, P.Y. Shepeliavyi, V.O Yuhymchuk, V.V. Melnyk, A.G. Kuzmich. Selfsustained cyclic tin induced crystallization of amorphous silicon. J. Mater. Res. 30, 3116 (2015).

23. V. Neimash, P. Shepelyavyi, G. Dovbeshko, A. Goushcha, M. Isaiev, V. Melnyk, A.G.Kuzmich. Nanocrystals growth control during laser annealing of $\mathrm{Sn}:(\alpha-\mathrm{Si})$ composites. J. Nanomater. 2016, 7920238 (2016).

24. V.B. Neimash, A.O. Goushcha, L.L. Fedorenko, P.Ye. Shepelyavyi, V.V. Strelchuk, A.S. Nikolenko, M.V. Isaiev, A.G. Kuzmich. Role of laser power, wavelength, and pulse duration in laser assisted tin-induced crystallization of amorphous silicon. J. Nanomater. 2018, 1243685 (2018).

25. H. Richter, Z.P. Wang, L. Ley. The one phonon Raman spectrum in microcrystalline silicon, Solid State Commun. 39, 625 (1981).

26. I.H. Campbell, P.M. Fauchet. The effects of microcrystal size and shape on the one phonon Raman spectra of crystalline semiconductors. Solid State Commun. 58, 739 (1986).

27. T.R. Hart, R.L. Aggarwal, B. Lax. Temperature dependence of Raman scattering in silicon. Phys. Rev. B 1, 638 (1970).

28. R. Tsu, J.G. Hernandez. Temperature dependence of silicon Raman lines. Appl. Phys. Lett. 41, 1016 (1982).
29. A.S. Nikolenko. Temperature dependence of Raman spectra of silicon nanocrystals in oxide matrix. Ukr. J. Phys. 58, 980 (2013).

30. B.P. Falcao, J.P. Leitao, M.R. Correia, M.R. Soares, H. Wiggers, A. Cantarero, R.N. Pereira. Light-induced nonthermal population of optical phonons in nanocrystals. Phys. Rev. B 95, 115439 (2017).

Received 01.03.19.

Translated from Ukrainian by O.I. Voitenko

В.Б. Неймаш, А.С. Ніколенко,

В.В. Стрельчук, П.С. Шепелявий,

П.М. Литвинчук, В.В. Мелъник, І.В. Олъховик

ВПЛИВ ЛАЗЕРНОГО СВІТЛА

НА ФОРМУВАННЯ І ВЛАСТИВОСТІ

НАНОКРИСТАЛІВ КРЕМНІЮ

В ШАРУВАТИХ СТРУКТУРАХ a-Si/Sn

$\mathrm{P}$ е $з$ ю м е

Методами комбінаційного розсіювання світла та оптичної мікроскопії досліджено вплив інтенсивності лазерного світла і температури на кристалізацію аморфного кремнію, індуковану оловом. Експериментально показано існування не теплових механізмів впливу лазерного світла на формування нанокристалів кремнію та на їх Раманівський спектр. Фотоіонізація кремнію та електрон-фононна взаємодія розглядаються як можливі причини виявлених ефектів. Обговорено перспективи їх застосування в нових технологіях виробництва плівкового нанокремнію для сонячних елементів. 